\title{
Configurações
}

Revista de sociologia

\section{Virtual experience, collective memory, and the configurationmof the public sphere through the mass media. The example of Ex-Yugoslavia}

Experiência virtual, memória coletiva e configuração do espaço público através dos mass media. 0 exemplo da ex-Jugoslávia

Expérience virtuelle, mémoire collective et de la configuration de la sphère publique à travers les médias de masse. L'exemple de l'ex-Yougoslavie

Jeffrey Andrew Barash

\section{OpenEdition}

\section{Journals}

Edição electrónica

URL: http://journals.openedition.org/configuracoes/3280

DOI: $10.4000 /$ configuracoes.3280

ISSN: 2182-7419

\section{Editora}

Centro de Investigação em Ciências Sociais

Edição impressa

Data de publição: 27 Junho 2016

Paginação: 11-29

ISSN: 1646-5075

\section{Refêrencia eletrónica}

Jeffrey Andrew Barash, "Virtual experience, collective memory, and the configurationmof the public sphere through the mass media. The example of Ex-Yugoslavia », Configurações [Online], 17| 2016, posto online no dia 30 junho 2016, consultado o 21 abril 2019. URL : http://journals.openedition.org/ configuracoes/3280 ; DOI : 10.4000/configuracoes.3280 
Barash, Jeffrey Andrew - Virtual experience, colective memory, and the configuration of the public sphere through the mass media. The example of ex-Yugoslavia. Configurações, vol. 17, 2016, pp. 11-29

\title{
Virtual experience, collective memory, and the configuration of the public sphere through the mass media. The example of Ex-Yugoslavia
}

\author{
JEFFREY ANDREW BARASH*
}

Princeton University

\section{Resumo \\ Experiência virtual, memória coletiva e configuração do espaço público através dos mass media. O exemplo da ex-Jugoslávia}

Ao longo do século XX, o espaço público sofreu uma série de modificações que estão em estreita relação com as transformações dos mass media. No mundo contemporâneo, são a imagem televisiva, a internet, a world wide web e os diferentes tipos de tecnologia digital, na sua familiaridade e ubiquidade, que dão uma configuração ao espaço público. Este artigo interroga-se sobre as mutações nos modos de organização da experiência e da memória pública, colocando em destaque o modo como os mass media selecionam, organizam e transmitem a reportagem dos acontecimentos, dando-lhe uma visibilidade pública. Esta análise toma como base empírica o exemplo concreto fornecido pelas guerras dos Balcãs nos anos 1990.

Palavras-chave: mass media, hipermédia, Amselfeld, guerras balcânicas, últimas notícias, vídeo, memória coletiva.

\begin{abstract}
In its different manifestations in our contemporary mass societies, the public realm has undergone a series of fundamental transformations over the course of the past century. A comparison of the present-day organization of the public realm with that which predominated among earlier generations, above all prior to World War II, illustrates that these changes correspond to metamorphoses in the mass media: the televisual image, the internet, the world wide web and accompanying types of digital technology, in their ubiquity and familiarity, lend pattern to the public sphere in its contemporary form.
\end{abstract}

\footnotetext{
* Fellow at the Institute for Advanced Study, Princeton University. Email: jabarash@gmail.com.
} 
Through illustrations drawn from the Bosnian and Kosovo conflicts of the 1990s, this article focuses on mutations in the modes of organization of public experience and public memory that have emerged over the past decades. According to its central argument, the great technical advances of mass communications have brought forth their uncanny capacity to simulate direct experience through images while dissimulating the gap which separates communicated information from the immediate life world in which it originates. In this framework, the format of mass communications has become a principle contemporary source of public visibility, indeed of an iconic status which, as it is publicly conveyed and remembered, is readily translated into mass celebrity and novel contemporary forms of public influence.

Keywords: mass media, hypermedia, Amselfeld, Balkan wars, breaking news, video, collective memory.

\section{Résumé}

Expérience virtuelle, mémoire collective et de la configuration de la sphère publique à travers les médias de masse. L'exemple de l'ex-Yougoslavie

Au cours du 20ème siècle, le domaine public a subi toute une série de modifications qui sont dans un étroit rapport avec les transformations des médias de masse. Dans le monde contemporain, c'est l'image télévisuelle, internet, le world wide web et les différents types de technologie digitale, dans leur familiarité et leur ubiquité, qui donnent une configuration à l'espace public. Cet article s'interroge sur les mutations dans les modes d'organisation de l'expérience et de la mémoire publique en mettant en relief la manière dont les médias de masse sélectionnent, organisent et transmettent le reportage des événements en leur accordant une visibilité publique. Cette analyse prend comme base empirique le exemple concret fournit par les guerres des Balkans des années 1990.

Mots-clés: médias de masse, hypermédia, Amselfeld, guerres balkaniques, information de dernière heure, vidéo, mémoire collective.

The public realm comprises a system of organization of collective experience and collective remembrance as it is projected to lend pattern to shared events in the future. In its different manifestations in our contemporary mass societies, the public realm has undergone a series of fundamental transformations over the course of the past century. A comparison of the present-day organization of the public realm with that which predominated among earlier generations, above all prior to World War II, illustrates that these changes in the public sphere correspond to metamorphoses in the mass media: in unprecedented ways, the televisual image, the internet, the world wide web and accompanying types of digital technology, in their ubiquity and familiarity, lend pattern to the public sphere in its contemporary form.

In the following pages I will examine this mutation in the modes of organization of public experience and public remembrance by focusing above all 
on the ways in which the mass media select, articulate and transmit reported events. In the course of my analysis I will illustrate this theoretical reflection by means of a concrete example: the Bosnian and Kosovo conflicts that accompanied the disintegration of Yugoslavia in the 1990s. In the mediatized representations these and other forms of what are customarily characterized as current events or "breaking news", the role of the media is not limited to selection, configuration, and communication of events; they also confer public significance on events while interweaving them into the broader web of what may be collectively recalled. In conferring public significance in this manner, the media organize the ways of collectively experiencing and remembering through which the public sphere is shaped; transformations in the media and in their ways of patterning collective experience and remembrance bring about corresponding metamorphoses in this function through which the public sphere is shaped. To identify what I take to be modifications in the modes of collective experience and remembrance brought by changes in the media, we must in preliminary fashion clarify the terms "collective experience" and "collective remembrance" themselves and then more closely examine the dynamics through which the mass media lend them pattern in contemporary mass societies.

I. Since collectivities have no substantial being independent of the individuals who compose them, they can never be said to "remember" in any strict sense of the term. According to its primary signification, remembrance is carried out in the original sphere of the self and may be shared and communicated where it occurs among groups. Original experience and remembrance concerns people and things, events and situations as they actually present themselves in a direct encounter, so to speak, “in the flesh". My understanding of this term draws on phenomenological theory, above all of Edmund Husserl, who equated original experience with what he termed "experience in the flesh in a given living present" ("leibhafte Erfahrung in einer jeweiligen lebendigen Gegenwart"). ${ }^{1}$ In its full sense, this signifies not only the perception of persons or things as single objects, but above all an encounter with them as they are given in the horizon of a surrounding world. The foreground upon which the observer focuses in such direct encounters presupposes a background, the plenitude of an accompanying context which is simultaneously given, even where the observer pays no attention to it. Where it is not explicitly noticed and stands at the horizon of the direct theme of attention, its passive presence may in many cases be made a topic of recall where an effort is made to retrieve it.

On the level of events that are of public significance, direct "in the flesh" experience and recollection are rare, and in such cases they usually concern 
a very small number of individuals who were direct actors in, or eye-witnesses to the events. Where members of a community, as vast as it may be, share remembrances of what can be publicly communicated through word, image and gesture, this remembrance is generally indirect. In attributing to recollection of in the flesh encounters the status of original remembrance, $\mathrm{I}$ in no way intend to claim that such remembrance would somehow recall the "reality" of what is encountered, if this is taken to mean that it might be experienced independently of the singular perspective of the observer. All direct encounters are remembered from a personal perspective or from that of a given group. Here we are familiar with the possibilities of distortion, omission and fabrication, even where they are unintentional, that may enter into the remembrance of direct encounters. This is why the comparison of testimonies plays such an important role in which the recollection of eye-witnesses is fit into the larger web of events and its spatio-temporal and conceptual logic. In attributing an original status to remembrance of "in the flesh encounters", I claim only that they are essentially different from all other forms of mediated encounter which, moreover, presuppose this original form of direct experience. For this reason, in spite of the evident weaknesses of eye-witness testimonies, they play a singular and indeed irreplaceable role in our judicial systems and in the quest of historiographical methods to reconstruct the factual truth of past events.

If in its multiple manifestations the public sphere generally lies beyond the realm of personal and small group experience and remembrance, it nonetheless provides the broad context in which mass communication and also interpersonal relations transpire. It is in this context that original experience in the flesh and small group relations are endowed with communicable significance to the extent that they are embodied in symbols. Symbolic embodiment, as I understand it, is not an aspect of experience that is tacked onto it as a secondary addition, but configures it at a primary spatio-temporal and conceptual level. ${ }^{2}$ Even before reflecting on them, we are immediately familiar with spatio-temporal and conceptual relations that govern our everyday world: for example, taking one's hat off in acknowledgement of the sacred space of a church, the spontaneous distinction between the private area of a backyard and that of publicly accessible parks, the anticipation in given cities that markets will be closed on Monday mornings and not on Wednesdays. Even the distinctions in the music I hear as it is piped into supermarkets and airports or played live at concerts or discothèques involves modes of symbolic patterning of space and 
time which, for the most part, are tacitly remembered as modes of orientation for immediate everyday activity.

In referring to the public sector of a vast collectivity in which the mass media evolve, my analysis presupposes the ever greater predominance of social, political and economic contexts that are no longer structured on a local or communal scale, in other words our contemporary situation that has followed in the wake of the industrial and then the technical and information revolutions, of the ever more rapid mobility of people and goods accompanied by mass migration toward urban centers and the integration of finance and of markets on a global scale. Where smaller groups, families and close-knit communities share similar kinds of experience that draw on a web of personal recollections interwoven with those of living generations who remain in close proximity, mass societies integrate groups whose modes of experience may well be unfamiliar to each other and whose relations are characterized by anonymity far beyond that of smaller and more intimate social circles. The fragmented social contexts of mass societies are encompassed in a given shared present in what I term a shared "horizon of contemporaneity", the perspectives of different groups rooted in symbol systems that may overlap, such as when they share a common language, but which may also be nourished by diverse symbolic webs, in relation to religious traditions, dialects, social practices etc., a network of remembrance through which experience is oriented in relation to a given group perspective and specific group expectations. However much similarity to one another the individual members of families, local associations and small communities might exhibit ${ }^{3}$, the public sphere, even in the most apparently homogeneous of mass societies, is marked by a mobility, a mutability of personal and social forms of existence, and an exposure to external influences that has not only propelled them beyond the sphere of traditional communal life, but has essentially transformed their ways of being together in a common world. It is here that the mass media both mirror and configure ways of experiencing and of remembering, as well as future expectations, through which the public sphere assumes its contemporary pattern. In bringing to visibility what ordinarily lies outside the range of direct vision, and in conferring on it a public significance, the role of the media is by no means limited to reporting events, but they constitute the primary mode through which current preoccupations and events that ordinarily stand beyond the possibility of direct experience are publicly accounted for and retained in memory.

Beyond the perspective of a specific community and of the broader reach of a given public, the scope of the media is continually and ever more comprehensively extended on a global scale to encompass foreign symbolic networks,

3 The "Sphere of communal familiarity" ("Sphäre gemeinschaftlicher Vertrautheit"), according to Helmut Plessner's apt phrase; cf. Plessner (1981: 55-56). See also in this regard Gerhardt (2012: 202-207). 
most of which lie beyond the realm of direct comprehensibility to those who receive what the mass media report. Here a given public is largely dependent on media accounts which translate and interpret what would otherwise be incomprehensible. In this manner the media simultaneously bring to visibility the concentric spheres of community, collectivity and global totality which, whether communicated through print or through visual image, exercise what I term a "reflexive function" in their capacity to endow what has been directly witnessed by a small minority with public status, ${ }^{4}$ while opening it to the global reach of the information network. In the process of selection and ordering, information is organized according to the spatio-temporal pattern and logic that is specific to mass communication systems. This spatio-temporal pattern and logic are not simple copies or replicas of those that govern everyday experience in the flesh and remembrance of that experience; they constitute an autonomous mode of symbolic embodiment through which public awareness is engendered and channeled and their overarching horizon of contemporaneity is configured. And, what is more, this spatio-temporal pattern and logic, far from a fixed property, is subject to modification in relation to the technical organization of the media themselves through which information is communicated. It is here that we must locate the principal change that has occurred in the way in which the media pattern the public sphere.

II. If we are to pinpoint the essential dynamic in the mass structuring of public experience and public memory, in anticipation of a common future, the decisive metamorphosis that has occurred may be traced in important measure to the role that the image has come to play in our contemporary world. Images, of course, are not recent appearances and, in considering their significance, it is not possible to limit their role to what the mass media disseminate. In earlier contexts, art and design provided the principle traditional ways by which images were endowed with public visibility. Images brought before the public eye artistic, political, theological or economic messages that iconography explores in historical perspective. Following the emergence of the mass media and the technology of mass reproduction, however, images assumed an ever more central role: beginning with the Crimean War of 1854, the American Civil War of the 1860s and the Franco-Prussian war of 1870-71, war correspondents served as eye witnesses to events, who sketched images of them for the mass editions of contemporary newspapers and illustrated journals. ${ }^{5}$ The role of the images steadily increased in fashion magazines and illustrated weekly

\footnotetext{
4 Here I draw on the insightful remarks of Niklas Luhmann (2000: 97): "The function of the mass media lies after all that in the directing of self-observation of the social system [...] an observation which itself generates the conditions of its own possibility and in this sense occurs autopoietically".

5 Jackson (1885), Baleva (2012).
} 
journals. With the invention of photography, the role of the image became ever more prominent, and this role was at once reinforced and transformed with the introduction of moving pictures, from movie and newsreel to televised video news and entertainment programs and a host of digitalized forms of communication which have accorded to the image and the culture of the image an ever more central role.

In all of its expressions, traditional or contemporary, the potency of the image lies in its capacity to reproduce the singularity of direct sensuous experience which language can only indirectly convey. Like language, images emerge in the context of specific symbolic networks, but are at the same time characterized by a certain plasticity which lends to them a unique autonomy. Where language and other signs anchor sensuous images in a specific context, images, as publicly interpretable visual phenomena, retain the capacity to overstep the confines of the context in which they emerge - their embeddedness in a specific horizon of contemporaneity - to spontaneously communicate a sensuous meaning. ${ }^{6}$ Languages, of course, may be translated, and in this modified form step across linguistic borders to speak to other, foreign contexts. Nonetheless, without translation, language and other contextually bound signs are incomprehensible to those who are not familiar with them, but the sensuous plenitude of the image reaches spontaneously beyond these limits. In its immediacy, indeed, the image approaches much more closely than linguistic description the direct sensuous presence of in the flesh encounters.

To illustrate this potency of the image, we may take as an example an image related to ex-Yugoslavia: the painting The Kosovo Maiden (Kosovka Djevojka), created in 1919 by Uroš Predić and exemplifying the realist style in Europe that was popular in the late $19^{\text {th }}$ and early $20^{\text {th }}$ centuries. The painting, as is generally familiar to inhabitants of the Balkan peninsula, depicts a famous legend, stemming from the loss of the battle of Kosovo in 1389 against the Turks. This theme became prominent in a tradition of Serbian epic poetry which, since the Middle Ages, has brought forth a range of sedimented symbolic meanings that have been associated with it since then. At the same time, this image of the Kosovka Djevojka expresses a certain autonomy in relation to its original context, since it conveys a spontaneous sensuous significance, albeit one that lends itself to interpretation by the various peoples of the Balkan region in light of their specific historical and religious traditions. In the same horizon of contemporaneity in which they live, the sense of the image varies in terms of the fragmented perspectives corresponding to their respective contexts.

6 Following the introduction and spread of the printing press in the $15^{\text {th }}$ and $16^{\text {th }}$ centuries images, as they were reproduced for the first time in large numbers, exerted a novel influence for, as Aby Warburg aptly stated, the sensuous 'language' these 'stereotypical' images ( $\underline{\text { Schlagbilder}}$ ) communicated was “internationally understandable', cf. Warburg (2010: 456). 
If we examine more closely this autonomy of images, we notice not only that they manifest a surplus of possible meanings in relation to any given context in which they are interpreted, but also that they are capable of communicating a free-floating sensuous symbolism, which frees itself from the original horizon of contemporaneity in which it arises. If I consider the painting Kosovka Djevojka, for example, it may be that the painting pleases me and at the same time portrays a certain stylistic resemblance to other contemporary European realist paintings of this period. However, if I am not familiar with the context to which the theme of painting corresponds, the complex range of its iconographic significations remains as impermeable to me as the languages spoken on the Balkan peninsula. In all of its forms, the image retains its capacity to exceed contextually embedded significations belonging to the horizon of contemporaneity of those who grasp these significations in the web of symbols interwoven in the segmented strata of memory shared by overlapping living generations. Reinforced either by aesthetic or other evocative qualities that strike us and resonate in memory, the image retains a certain autonomy in relation to the context from which it emerges. In its free-floating capacity to move beyond any singular, fixed standpoint, such images assume the role of "icons" or "key images" (Schlüsselbilder). ${ }^{7}$ On a scale of global dissemination, such key images or icons can reach a level of abstraction comparable to the omnipresent representations of Che Guevara or Marilyn Monroe. The photo of Che Guevara, which was originally taken in 1960 by the Cuban photographer Alberto "Korda" Diaz while Che was listening to a speech by Fidel Castro in Havana, was initially invested with political significance as it was subsequently displayed at political rallies and demonstrations or in student dormitories. This political meaning was eventually broadened and diluted as it was adopted in clothing styles as an eye-grabbing symbol of fashionable chic and was accorded further commercial significance when Smirnoff used it in advertising for vodka. In its free-floating versatility, the sense of such key images changes in relation to its context of presentation and reception. As publicly reproduced images on a global scale, key images are both immediately recognizable and indeterminate in content. As images, they are pregnant with different connotations rooted in the corresponding networks of embodied symbols that are retained in collective memory and that orient the interpretation of experience in the different contexts in which they are deployed. As icons or key images, they reveal a central trait governing the spatio-temporal pattern and the visual logic of the mass produced image as it is communicated in the public sphere: in its decontextualized form and free-floating autonomy, it draws immediate recognition without necessarily

7 See the insightful analysis of this theme by Zimmermann (2015: 91-116); see also in this regard the source that she cites, Ludes (2001). 
conveying a more determinate sense rooted in the original experiential world from which it emerges.

Since the pioneering work of authors like Georg Simmel or Walter Benjamin, we have increasingly oriented our reflection toward the ways in which mass reproduction has modified our manner of perceiving images. This modification has corresponded to the ever-increasing use of images in all aspects of public and private life which, on one hand, are transmitted by ever more diversified types of media and, on the other, encompass disparate kinds of message that the media continually and ubiquitously bring to public visibility. Commercial advertising, entertainment and sports, news broadcasting and political announcements as well as the imagery of sexual allure are among the most common types of imagery produced for mass consumption and assimilated within formats of mass dissemination. Over the course of the $20^{\text {th }}$ century, artists themselves were among the most energetic producers of mass reproduced images, for they recognized the unprecedented possibilities of the mass media as a means of forging visual icons and of bringing them before the public eye. Major currents of $20^{\text {th }}$ century art such as DADA or surrealism creatively explored these possibilities and Pop Art, above all, specialized in the production of icons that, as decontextualized images at the nebulous crossroads between different sectors of public life, provided ideal objects to be formatted for mass consumption. Andy Warhol is a case in point, for he began his career in commercial graphics, and his images brought together in a paradigmatic way different overlapping themes in which the motifs of art, of news, of advertising or fashion, were blended into icons fit for mass consumption. Warhol's representation of the Campbell's soup cans, of the scenes of fatal airplane crashes and car accidents, of the multiple, diversely colored images of Marilyn Monroe, all presented as icons, immediately reach beyond the specific cultural context of their origin and are fit for mass consumption on a global scale. ${ }^{8}$

This same kind of icon may also function on a regional level, as may be illustrated from a Balkan perspective. In 1984, in what was then Yugoslavia, the Sarajevo based rock group "Bijelo Dugme" produced an enormously popular record album for which the name of the group served as the title. On its cover the album bore a representation of the painting by Uroš Predić, Kosovka Djevojka. The songs in this album made subtle reference to the previous album of the group ("Uspanavka za Radmilu M.”, 1983), in which one song ("Kosovska", signifying song of Kosovo, but also connoting, as a play on words, “Kosovo Maiden”), was sung in Albanian while the other songs on the album were performed in the more usual Serbo-Croatian language. Without

8 Although it is often attributed to him, Andy Warhol did not create the juxtaposed series of "Guerillero Heroico" images that was made in a style resembling his works. This work was originally a falsification that, following the request of its Italian creator, he "authentified"; see in this regard Bourdon (1995) and Ziff (2006). 
being nationalistic, the album reflected a renewal of interest in national identity and in traditional folklore which the cover exemplified. Its commercial success may be accounted for by its manner of mixing ethnic themes, offering a product with which an ethnically diverse audience could readily identify. Beyond the image originally painted by Uroš Predić in 1919 and beyond the specific context of the scene that he depicted, the Kosovo maiden could function as an icon, a "Schlüsselbild". In its mass-produced format, it could assume a role analogous to other such commercial and artistic productions in a global, or at least in a multi-ethnic regional market. Such products meet with success the better they are capable of obliquely reflecting the context from which they emerge, in a way which dispenses the observer from a need to delve into its more specific contextual contours and its embeddedness in the horizon of contemporaneity which, for better or for worse, is nourished by deeper sources of collective remembrance lending it a publicly intelligible significance for the community in which it arises. As a product of mass consumption, the Kosovka Djevojka could take on a funky folk allure in which the indeterminacy of its context corresponded to its commercial marketability before a mass audience.

Five years after the appearance of this album, Miloševićs 1989 Gazimestan speech, presented on the presumed site of the Amselfeld battlefield, sought to reenlist the Battle of Kosovo for the purposes of Serb nationalism and this event cast an ominous shadow on the kind of funky and folklorish perspective it might convey. It would reach beyond the scope of the present paper to examine the ways in which Milošević invoked the theme of a collective memory as it reached deep into the historical past and, as his Gazimestan speech made amply clear, fueled the quest to recover what his followers took to be a lost medieval heritage and the territory which it had originally encompassed. I will cite rather a third example provided by a globally publicized response to the wars that such regional nationalism fueled: in particularly radical form, the Benetton publicity campaign of Oliviero Toscani illustrates the intrinsic dynamic of images which the mass media bring to public visibility and disseminate on a global scale.

In a publicity campaign, photographer and graphic designer Oliviero Toscani, by means of well-known shock images, promoted Benetton clothing while simultaneously directing public awareness toward social issues. His goal was to expose a whole range of social taboos. One of these campaigns was undertaken in 1994, during the Bosnian war, when Toscani intended to illustrate the absurdity and the cruelty of war through what he called his "photographic monument to a known soldier". This photographic monument depicts the young Marinko Gagro, who had been killed in action and was represented in the photo only by his blood-stained clothing and an accompanying typed comment of his father. Neither his uniform nor the content of his father's message call attention to the specific country or cause for which he fought and highlight above all the 
loss his death represented. The image was thoroughly decontextualized and the anonymity of Toscani's mode of depicting his death was highlighted by the ambiguity of its message: a scene of horror that was publicly displayed in the form of an advertisement for clothing. As Toscani himself reported, this ambiguity was underscored by a group of young Sarajevo graphic designers who wrote a letter to him and described the photo in the following terms:

We will never know if this poster concerned with the conflict in our region is one of the most insolent and cynical reactions or if, on the contrary, it is not one of the most skillful warnings in regard to this deep and atrocious wound perpetrated by modern civilization, which seems to accord an ever greater role to marketing and communication. ${ }^{9}$

III. Unlike paintings, still images or photographs, moving pictures, first in film and newsreel and then in video and digital communication, move in time. Their movement in time likens them to the temporality of animated beings and lends them the capacity, beyond any other kinds of pictorial representation, to simulate direct experience "in the flesh". This capacity, it must be stressed, is limited to simulation which, even in the most immediate representation through video or numeric images depends on the interface by means of which they are mediated and transmitted. Insofar as they depend on an interface, even the most technically immediate forms of video or numerical representation, such as the image of oneself that one sees on the video screen displayed in a store window one happens to walk by, video and digital representations remain virtual reconfigurations. In their simultaneity, they duplicate the spatio-temporal coordinates of the Lebenswelt they represent and yet, as virtual images, they are cropped out of and abstracted from the complex plenitude of its experiential context. They represent in this form what might be termed a "mediated immediacy". It is the possibility of recording, condensing and rearranging moving images in accord with the decontextualized and free-floating virtual format that fits them out for mass consumption on a regional or global scale. Such virtual engagement in the representational sphere of moving pictures cannot be termed experience in the strict sense of the word, as nearly as it may simulate experience and as much as remembrance of them may transpire for us "as if" we were recalling direct encounters "in the flesh". Virtual representation, indeed, obeys a spatio-temporal pattern and a logic which is not equivalent to that of experience and herein lies the specific character intrinsic to moving pictures as forms of mass communication: on one hand, through their capacity to simulate the animation of experience "in the flesh" they come infinitely closer to replicating it than print media or even still

9 Toscani (1995: 92-93). 
images; on the other hand, due to their limits as virtual representations they are, like other forms of mass communication, incapable of bridging the gap that separates them from the plenitude of the Lebenswelt. And here, in spite of the uniqueness of their capacity to simulate direct experience, their mode of operation in the format of mass communications realizes the utmost possibilities of a dynamic that was already implicit in earlier forms of mass communication, beginning with the mass-produced print media. Here in bringing to fulfillment an uncanny ability to simulate direct experience, they are all the more effective the more they are able to dissimulate the distance which their format as mass communication necessarily maintains from it. And herein lies their particular potency and also a specific danger that their reflexive function as organs of public awareness poses for the political organization of the public world more generally.

Contemporary advances in digital technology and satellite communication have realized to an unprecedented degree a quest that was incipient in the earliest forms of mass media: to bring within reach the most minute segments of the globe, as distant as they may be, and to convey information as rapidly as possible in a constant and ubiquitous process of updating. In terms of the reflexive function of the media through which they are made the principle organ of public awareness, this global reach and constant process of updating privileges what is novel and previously unknown, the "news" through which the most recent events in all sectors may be juxtaposed and made visible as objects of public interest. Here, according to a principle that had already predominated in the organization of newspapers ${ }^{10}$, the condensed format and haphazard arrangement juxtaposes or places in immediate succession such heterogeneous elements as advertising and "breaking news", sports events and stock market reports. Moving images on the main body of television screens are bordered by moving printed strips on the lower margin of the "hypermediated" display in contemporary CNN-like television announcements, and these mosaics have more recently given rise to ever more elaborate kinds of display on the pages of the world wide web or the Windows touch screen format. ${ }^{11}$

All of these forms of visibility of the image before a mass public depend on a specific order that shapes publicly remembered virtual representations; it is a symbolically configured order not because it assumes the form of a sign or emblem, but due to the immediate spatio-temporal pattern and logic it deploys in the operations of displacement, condensation and reconfiguration of information in a manner that, so to speak, grabs the public eye as it represents moving images as current events. The condensed format and heightened immediacy

10 Walter Benjamin, aptly characterized the principles of journalistic information as "freshness of news, brevity, comprehensibility, and, above all, lack of connection (Zusammenhangslosigkeit) between individual news items"; cf. Benjamin (1968: 158-59).

11 On the concept of "hypermediation" see above all Bolter and Grusin (2000). 
of media news transposes images from the horizon of contemporaneity of given groups in which original experience transpires, and is remembered and communicated, to what might be termed its "field of currency". ${ }^{12}$ In the field of currency, the media present information that is continually updated and lend it a spatio-temporal pattern and logic that formats it for mass dissemination. The abridged, condensed and reconfigured format of the field of currency introduces a gap between their mode of presentation and the horizon of contemporaneity in which everyday experience and remembrance transpires. This, of course, does not mean that that moving images and information communicated in virtual form would somehow remain separate from the domain of direct everyday experience, for virtually depicted events work back on experience and enter into the configuration of the web of embodied symbols that underlie the horizon of contemporaneity of a given group. This is the essential role of what I am terming the "reflexive function" of the mass media. The virtual depiction of events can often assume far greater importance than what we immediately experience in the everyday Lebenswelt. There are even instances - and the Bosnian and Kosovo conflicts of the 1990s are a case in point - where victims of attack could simultaneously witness events that they we undergoing on the television screen ${ }^{13}$.

Nonetheless, this gap between virtual representation and direct everyday experience remains an essential feature of our public existence even if it is not always brought to awareness. The decontextualized mode of presentation of breaking news in the field of currency renders problematic the logic of verification that we employ in everyday experience by which we test the reality of reported facts by comparing different sources and types of testimony provided by the broader web of experience in the horizon of contemporaneity. It

12 The concept of the "field of currency", in which the spatio-temporal and conceptual format of mass communication is configured, like that of the "horizon of contemporaneity" on which it works back, refer exclusively to the public domain of group experience and remembrance. These concepts are to be distinguished from specifically historical categories that correspond to essentially different modes of temporal experience. As I interpret them, the "horizon of contemporaneity" and the "field of currency" are limited respectively to the time-span of living, overlapping generations and to the ephemeral moment during which news of reported events maintain its currency. If, as they are employed, both of these concepts might be encompassed in what Reinhart Koselleck terms the "space of experience" ("Erfahrungsraum"), they nonetheless correspond to entirely different kinds of group experience than those denoted by Koselleck's historical categories. According to Koselleck, the modern experience of historical time emerged in the $18^{\text {th }}$ and $19^{\text {th }}$ centuries, when history was conceived for the first time to be an autonomous, self-sustaining process. Since history in the "space of experience" is interpreted to be a unified process, history may be envisioned as a future that remains to be realized in the framework of a given "horizon of expectation" ("Erwartungshorizont"). See Koselleck (1979: 350-353). Since my analysis is primarily concerned with public experience and collective remembrance, it relates less to such uniform categories of historical time than to a plurality of fragmented temporal perspectives that interrelate in a mass social framework.

13 This plausible scenario experienced by war victims was recently reported in the Frankfurter Allgemeine Zeitung: "The wars in Yugoslavia illustrate beside many other forms of horror the perversity of the new world of the media: Victims of violence were able to simultaneously see themselves portrayed as victims on the T. V. screen". See Berking (2013: 26). 
is precisely the uncanny ability of visual imagery presented by the mass media to simulate direct experience which ordinarily leads us to overlook the specific character of the reconfigured spatio-temporal pattern and logic of representation of virtual accounts. And, even where we bring this specific mode of reconfiguration to awareness, it is not always possible to detect the operation of external factors influencing the selection and organization of reported events. In the political sphere, on one hand, the condensed and concentrated format of representation facilitates simplification of the real plurality of the public world where the viewpoint of a predominant group and its elite monopolize the space of public visibility; the Bosnian and Kosovo conflicts have amply demonstrated how politically problematic such tendencies may prove. On the other hand, commercial factors, commanded by the competition to attract the largest possible audience are subjected to evaluation in terms of the omnipresent ratings or "audimat", which play a role in the programming selections not only of entertainment shows, but even of news programs. ${ }^{14}$ And commercial considerations play an ever more central role, which is often not recognized as such, in the modes of representation in the internet. My point here is that the format itself of mass communication facilitates the possibility for such political and commercial factors to influence the selection of reported events and the way in which they are made publicly visible; here they may not only limit but also distort the reflexive function of the media through which events are brought to mass awareness and retained in collective memory.

The convergence of political, commercial and other factors in the modes of representation of the mass media only heightens their ambiguity, much as in the case of mass-produced still images. Moving images, in their ability to simulate direct experience, may combine with particular effectiveness different kinds of message which, abstracted from their original context, are nonetheless charged with an implicit iconic sense that draws on latent symbols embodied in the web of collective remembrance of a given group to which the message is addressed.

Let me cite one further example which is relevant both to my analysis of the patterning of the public sphere by the mass media and of their operation, more specifically, in the traumatic Balkan conflicts: the representation by the media of sports. In the context of modern societies, spectator sports fulfill a number of different vicarious functions and this variety is reflected in the ways in which the media represent them. Helmuth Plessner has eloquently characterized the plurality of ways in which sports competition provides the ideal channel through which a series of needs stimulated by contemporary social life may be fulfilled: As Plessner writes, 
The need for relaxation and social contact, for aggressivity and play, for competition and activity, as for hero worship, tends toward public expression and is fulfilled through sports. ${ }^{15}$

In a paradigmatic way, this plurality of functions of sports in contemporary mass society is particularly well adapted to the essential ambiguity of media phenomena, by which the mass media indifferently combine political, commercial, entertainment and other kinds of message that are propelled by a variety of partially hidden factors stemming from different areas of social activity. The variety of needs that spectator sports satisfy in bringing competitions before the public eye, corresponding to the ambiguity of roles that sports images combine, lends them enormous popularity and confers on them the power to promote a whole series of interests involving sports club owners, high finance, media representatives and very often, as recent experience amply demonstrates, political figures at the highest levels of command. This phenomenon is well known in contemporary Europe, as illustrated by the famous example of Silvio Berlusconi in Italy, who became a powerful media figure in the early 1970s, concentrating his private television companies into nationwide networks, Canale 5, Italia 1, and Rete 4. In the mid-1980s he acquired the Italian football club, A. C. Milan, and became as a key Italian political figure, serving as prime minister three times between 1994 and 2011, before being convicted of tax fraud in 2013. In similar fashion, Bernard Tapie in France combined his power as owner of the Olympique de Marseille football club with a political role as minister of urban affairs in the socialist government during the second mandate of François Mitterrand, from which he was forced to resign in the wake of corruption charges in the early 1990s. Tapie has also been a television personality and an actor in the cinema and his involvement in high finance has led to much controversy. Berlusconi and Tapie, however, are only two of many examples which illustrate that the mass appeal of associations with spectator sports - whether as influential owner or player - is a source of media presence and public notoriety that is readily translated into political power. Arnold Schwarzenegger as champion weightlifter turned cinema celebrity and then governor of California or boxing world champion Vitali Klitschko as leader of an Ukrainian political faction became the mayor of Kiev illustrate the emergence of this phenomenon in recent decades on a global scale.

Mediatized sports events, and above all football, also played a key role in the Balkans where, as has been amply demonstrated, they served to channel expressions of ethnic nationalism as early as the mid-1980s when Yugoslavia still existed as a nation. In particular, the Zagreb based Dinamo team and the 
Serbian Crvena Zvezda or Red Star football club, whose matches were continually before the media, were early vehicles of nationalist sentiment which became increasingly vehement as the Yugoslav State neared collapse. As historian Ivan Čolović has noted, these matches furnished an opportunity for militant Croat Dinamo supporters to publicly recycle Ustashe symbols and the Crvena Zvezda spectators to publicly recycle songs, slogans and banners that drew on the Serbian Chetnik folklore from the Second World War. ${ }^{16}$ In their ambiguity, sports matches not only provided media events and commercial publicity of the first order, but their political role became increasingly significant in the public sphere. As Čolović illustrates, even in the period of Yugoslav communism, political leaders played a central part in the direction of Crvena Zvezda, but this political direction took on a wholly different character as national antagonisms emerged at the end of 1980s. ${ }^{17}$ Here, as the Serbian case demonstrates, hooligan spectators at football matches formed the core of the paramilitary forces led by the notorious Željko Ražnatović or “Arkan”, whose ultranationalist "Tigers" were held responsible for war crimes in the ensuing conflict in Bosnia. Ražnatović was the owner of the Obilić football team in Serbia, named after the hero of the battle of Kosovo, and he at the same time assumed an important political function as leader of the Serbian unity party. As the Milošević government centralized the predominant sectors of the mass media, purged a large number of journalists, and placed the media under strict government control, the earlier ambiguity of sports matches gave way to armed conflict during which a policy of media manipulation instrumentalized them as organs of the official ideology. The simultaneous reinforcement of government control of the mass media was also brought about by the Tudjman government in Croatia and the alignments of the different mass media systems in the Balkans closely reflected their ideological leanings in a period of war.

The reinforcement of national ideology through government control of the mass media limited the trans-ethnic appeal they assumed in the earlier Yugoslavian context and realigned them more explicitly in terms of national perspectives and political mythologies that reelaborated the legacy of a more distant past. Consider in this light in conclusion the example of the Serbian media icons represented by the sports club owner and paramilitary chief Ražnatović and his turbo-folk singer wife, Ceca. Presented live on national Serbian television in 1995, during a period that allegedly coincided with the brutal ethnic murders committed by him and his forces in Bosnia, the carefully prepared work of image production and promotion encapsulates in particularly blatant form the ways in which such icons are fabricated for mass consumption in the public sphere. Married in the uniform of a Serbian World War I officer, his 
appearance evoked the memory of patriotism in more favorable conflicts, while Ceca's flowing white dress, which was reportedly modeled on Scarlett O'Hara's dress in the film Gone with the Wind, underlined her stated desire to make of her wedding a fairy tale. The live transmission of the religious ceremony and of the festivities that followed over a period of many hours, during which Ceca herself performed, highlighted its multifunctional character, mixing military, political and religious rites and symbols which were conveyed before the television spectators in an entertaining show-business format. On the day following the wedding the national newspapers devoted extensive coverage to the event and, as if to reinforce the political mythology that surrounded it, an editorialist in the journal Duga likened Ceca to the Kosovka Djevojka. ${ }^{18}$

In spite of its political significance in the context of the Balkan wars, the success of the icon was by no means limited to Serbia, and it showed a remarkable plasticity in its capacity to cross national borders and adapt itself to very different kinds of contexts in which it was brought to public visibility. On Saturday, March $1^{\text {st }}$ 2003, a little over three years after Ražnatović's assassination in front of the same Belgrade hotel where her marriage festivities had occurred, the conservative and highly influential French Figaro Magazine published an article on Ceca, accompanied by a series of still photos. Titled "Madonna of the Balkans", the article underlined her flamboyant personality and her show business image, while downplaying her role as a folk icon and the political role her husband had accorded to her in the Serbian National Unity Party. The photos remodel the icon by presenting her as a faithful wife (only one of the four photos shows her with Ražnatović), a good mother and a highly successful business woman, a pop star and, following the death of her husband, as the owner and inspirer of the Obilic football club. Several years after the conclusion of the Kosovo war in which her dead husband had played such a notorious role and following the NATO strikes which led to Milošević's downfall, Ceca could appear in a new, decontextualized field of currency and the political mythology with which she had been associated could fade, especially in a non-Balkan context, to the point that she could appear, as stated at the conclusion of the French article, as the "Cinderella of Today." ${ }^{19}$ Here, the full ambiguity of such icons became most apparent where, beyond the specific horizon of contemporaneity in which they originated, the various facets of the image were tailored to different symbolic networks. In a decontextualized field of currency, the imagery of the mass media could reconfigure the image's ambiguous meaning and lend to it a quasi-mythological potency. The communicative power of this mythology is deployed by the unique symbolic potency that public visibility in the mass media confers and deposits in the recesses of 
public memory. Where in highlighting its ambiguity, the free-floating symbolism of the image configured by the mass media endows it with a spontaneous force, only contextual analysis may critically evaluate the deeper significance of those obscured aspects of the image that constantly risk being forgotten.

\section{References}

BALEVA, Martina (2012), Bulgarien im Bild. Die Erfindung von Nationen auf dem Balkan in der Kunst des 19. Jahrhunderts. Köln/Weimar/Wien: Böhlau.

BARASH, Jeffrey (2012), “Articulations of Memory: Reflections on Imagination and the Scope of Collective Memory in the Public Sphere". Partial Answers. Journal of Literature and the History of Ideas, 10 (2): 183-195.

BENJAMIN, Walter (1968), "On Some Motifs in Baudelaire", trans. Harry Zohn, in Illuminations. New York: Schocken.

BERKING, Sabine (2013), “Imperium zerstörter Seelen. Der Zerfall Jugoslwiens hat eine neue Generation von Autoren hervorgebracht. Wie einige von ihnen schreibt auch Ismet Prcic über Kindheit und Jugend im Krieg”, Frankfurter Allgemeine Zeitung, Wednesday, April 3rd: 26.

BOLTER, Jay David, GRUSIN, Richard (2000), Remediation. Understanding New Media. Cambridge, MA: MIT Press.

BOURDIEU, Pierre (1996), Sur la télévision. Paris: Liber-Raisons d'agir.

BOURDON, David (1995), Warhol. New York: Abrams.

BUISSON, Jean-Christophe (2003), “Ceca, La Madonna des Balkans”, Figaro Magazine, March 1st: $50-54$.

CASSIER, Ernst (1994), Philosophie der symbolischen Formen, vol. 3. Darmstadt: Wissenschaftliche Buchgesellschaft.

ČOLOVIĆ, Ivan (2002), "Football, Hooligans and War", in The Politics of the Symbol in Serbia. London: Hurst and Company, 259-286.

GERHARD, Volker (2012), Öffentlichkeit. Die politische Form des Bewusstseins. Munich: Beck.

HELD, Klaus (1966), Lebendige Gegenwart. Die Frage nach der Seinsweise des transzendentalen Ich bei Edmund Husserl, entwickelt am Leitfaden der Zeitproblematik. Den Haag: Nijhoff.

HUSSERL, Edmund (1973), Zur Phänomenologie der Intersubjektivität. Texte aus dem Nachlass. Zweiter Teil: 1921-28, ed. Iso Kern, Husserliana, Band 14. Den Haag: M. Nijhoff.

JACKSON, Mason (1885), The Illustrated Press. Its Origin and Progress. London: Hurst and Blackett.

KOSELLECK, Reinhart (1979), Vergangene Zukunft. Frankfurt am Main: Suhrkamp.

LUDES, Peter (2001), Multimedia und Multi-Moderne: Schlüsselbilder. Fernsehnachrichten und World Wide Web-Medienzivilisierung in der Europäischen Wahrungsunion. Wiesbaden: Westdeutsche Verlag.

LUHMANN, Niklas (2000), The Reality of the Mass Media, trans. Kathleen Cross. Stanford, CA: Stanford University Press.

PLESSNER, Helmuth (1985), "Die Funktion des Sports in der industriellen Gesellschaft", in Gesammelte Schriften, vol. 10, Schriften zur Soziologie und Sozialphilosophie. Frankfurt am Main: Suhrkamp.

PLESSNER, Helmuth (1981), “Grenzen der Gemeinschaft. Eine Kritik des sozialen Radikalismus (1924)", in Gesammelte Schriften, vol. 5, Macht und menschliche Natur. Frankfurt am Main: Suhrkamp.

POSTMAN, Neil, POWERS, Steve (2008), How to Watch TV News. London: Penguin. THOMAS, R. (1999), Serbia under Milosevic. Politics in the 1990s. London: Hurst. 
TOSCANI, Oliviero (1995), La Pub est une charogne qui nous sourit. Paris: Hoëbeke.

WARBURG, Aby (2010), "Heidnisch-antike Weissagung in Wort und Bild zu Luthers Zeiten" (1920), in Aby Warburg, Werke. Frankfurt am Main: Suhrkamp.

ZIIFF, Trisha (2006), Che Guevara. Revolutionary and Icon. New York: Abrams Image.

ZIMMERMANN, Tanja (2015), "Semmeln in Rozna dolina. Eine Erinnerung aus Ljubljana und die Kriegsbilder aus Bosnien”, in Boris Previši , Svjetlan Lacko Viduli (eds.), Traumata der Transition. Erfahrung und Reflexion des jugoslawischen Zerfalls. Tübingen: Narr/Francke/ Attempto Verlag, 91-116.

Submitted: 15-01-2016

Accepted: 13-05-2016 
